\title{
BIOGEOCHEMICAL RESIDUES AS ETHNOBOTANICAL INDICATORS ${ }^{1}$
}

\author{
Elizabeth A. Coughlin $^{2 .}$ and Jonathan E. Ericson ${ }^{3 .}$
}

In America, the archaeological application of chemical residue analysis of the soil is really in its initial stages. Soil phosphate analysis has been the dominant method used to date, although there is occasional use of other parameters, such as $\mathrm{pH}$ by Weide, (1966) and the now classical C, N, P and Ca analysis of Cook and Heizer (1965).

Sjoberg (1976) has said:

"Phosphate analysis is not only suitable for locating and delimiting sites, but can also serve as a useful tool in the interpretation of intrasites relationships. Experimentally, the P content has been used in estimating population size and the duration or intensity of settlements; to determine subsistence base and describe general diets; and to establish relative or even absolute chronology."

This paper proposes to expand the data base of soil residue analysis, particularly with respect to plant residue, by suggesting a new method of Trace Typing which utilizes a measurement of Trace Element Concentration (T.E.C.) and an associated new parameter of Enrichment Ratio which employs dendrochronologic data and contemporary botanicals.

The development of this Trace Typing has been motivated by the concern that much evidence has been screened out on the back dirt of the archaeological site.

Increasingly we see the need to verify specific functional attributes to sites, features, tools and other items. Although macroscopic evidence is usually employed to test the validity of a

1. Center for Archeological Research and Development Publication No. 4

Paper presented at the Forty-fifth Annual Meeting, Society for American Archeology, Philadelphia, Pa., May 1-3, 1980.

2. Botanical Museum, Harvard University, Cambridge, Mass.

3. Peabody Museum of Archeology and Ethnology, Harvard University, Cambridge, Mass. 
proposed attribute, soil residue analysis potentially can be used to gain clearer or more complex additional data.

Recent works on organic residues are very promising. Rottlander and Schlichterle (1979) have successfully used gas chromatography and thin layer chromatography to identify residues of plants and animals on a series of sites including an open air Aurignacian loess site some 34,000 years old. Pollack, Chang, and Cronin (1977) have reported on the determination of $\mathrm{D}$ and $\mathrm{L}$ isomers of some protein amino acids present in soils. It does appear that organic residue analysis offers promising possibilities in approaching the archaeological site.

We are concerned with focusing on the examination of inorganic elemental components of site residues. Our preliminary findings suggest the potential of using elemental analysis to identify vegetal remains. If we are to expand the data base to include inorganic components of residues, there are three major questions to be asked.

1) What elements will be useful to examine?

2) What is the significance of elemental concentrations?

3) What type of strategy can be applied to implement this research?

\section{1) What ELEMENTS SHOULD BE EXAMINED?}

Obviously, we would like to examine elements which have low mobility within the soil profile under a variety of conditions. The field of geochemistry has been concerned with the mobility of elements in biogeochemical prospecting.

The mobility of elements determines their creation of a dispersion halo around an ore body. For our purposes, this information can be used to select suites of elements having low mobility.

Andrew-Jones (1968) described the relative mobilities of elements in a low temperature and pressure environment. In Table One, we have listed the elements which have low mobility (barred) and those having very low mobility to being immobile (stippled).

These elements should remain in the soil as residues under oxidizing and reducing conditions, and under acid, neutral to 
alkaline soil conditions. Table One indicates that there are 40 elements which should be retained with the soil profile.

Mobilization of elements is strongly influenced by Eh (ionization potential), $\mathrm{pH}$ and the stability of minerals within the soil.

Brooks (1972) described four main factors responsible for mobilization and distribution of the elements.

1) Mobilization due to breakdown of soil by weathering and leaching.

2) Adsorption of ions on clay minerals and humus. Clay has an ion exchange capacity of up to $100 \mathrm{meq} / 100 \mathrm{~g}$; humus has a 500 $\mathrm{meq} / 100 \mathrm{~g}$ capacity.

3) Surface enrichment of elements by plant material. Here plants cycle particular elements by absorping from the soil, incorporating into their tissue, and enriching the surface by littering. The humus layers will be enriched relative to the stability of metal complexes with organic matter.

4) Mobilization or fixation by soil micro-organisms, particularly bacteria. Although insignificant in weight, their metabolic processes effectively handle large quantities of material.

Given these four factors, we may immediately realize that there will be chemical partitioning between the mobile and immobile elements and the efficiency of chemical traps.

Notwithstanding the problems of mobility, there are 40 elements which may be useful in interpreting plant residue.

\section{2) What is THE SignifiCANCE OF ELEMENTAL CONCENTRATIONS?}

As a plant seeks to establish itself, it employs the following methods with respect to the elemental composition of the soil. - First, it demonstrates an exclusion mechanism through which qualitative and quantitative regulation of absorbed elements is accomplished. This mechanism occurs primarily at the roots, although it may occur somewhat in the canopy.

- Secondly, this action of elemental uptake is related to function, and that function is the production of compounds. These compounds range from metabolic intermediates, various vitamins and catalysts through pigments such as chlorophyll to particular enzymes such as those associated with respiration and membrane repair.

Some additional compounds produced demonstrated a "social" function, like those that promote mutualism, such as insect 
attractants for pollination purposes, for transmittance of seeds through edible fruits, or by cultivation for economic purposes that is food, medicinal, or industrial use.

Other compounds socially "protect" by repelling insects, fungus, herbivorous animals and man.

- Thirdly, in the event that the exclusion mechanism fails, or is overloaded, extraneous elements are translocated to the canopy, where exfoliation effectively provides elimination.

Hyper-accumulation has a number of promoters: e.g., overwhelming of the exclusion mechanism by very high concentrations demonstrates itself in geochemical prospecting indicators of ore deposits.

Metabolic disorders brought about about the first notice of hyper-accumulators by Agricola in 1467 in DE RE METAL$L I C A$. Agricola described the hyper-accumulators as "sicklooking plants".

Pathologies of respiration, insect or fungus infestation, and tissue degeneration demand the heightened production of the necessary remedial compounds. In the event that the remedial agent cannot keep up with the disease, we are likely to see, in fact, actual deposition of the element at the site of the pathology.

Stress is also a promoter of hyper-accumulation. Plants have been shown to hyper-accumulate as a result of stress induced by alternately subjecting the plants to nutrient-rich and nutrientpoor growth solutions.

This factor of environmental stress occurring to all plants in a particular ecosystem may display an overall pattern of hyperaccumulation as the community seeks to establish itself.

In response to a reduction in soil $\mathrm{pH}$, and thus increased availability of elements for uptake, one would expect a corresponding increase in uptake by plants.

Whatever the elemental accumulation, it becomes a factor in the identification of residues and in linking them to their source.

3) WHAT TYPE OF STRATEGy CAN BE APPLIED

TO COMPLEMENT THIS RESEARCH?

Wood and other plant materials such as gums, resins, reeds, grasses having use in construction and deposits of foods, 
medicinals, or cosmetics found at domestic, agricultural, religious or other types of archaeological sites could be identified by elemental pattern; with the residue being related to a source (ancient or modern) displaying the same pattern of elements similar to the matching of a blood or tissue type.

This Trace Typing of archaeological residues within the perimeter of a site can be accomplished by the following method.

TRACE TYPE METHODOLOGY

1. Establish perimeter of the site utilizing:

a. Direct observation

b. LAND SAT

c. Infrared spectrometry or photometry.

d. Search for anomolous concentrations in the leaf canopy such as that used in biogeochemical prospecting.

2. Feature location utilizing a larger rectangular grid of $5 \times 5$ meters or a relative size appropriate to the site and testing for:

a. Magnetic anomalies (magnetometer)

b. $\mathrm{pH}$ (probe:meter)

c. Conductivity (probe:meter)

d. Phosphates (chemical field kit)

e. Total Organic Carbon (laboratory or field lab)

Plot these results and produce contour maps.

3. Where anomalies occur, such as:
a. Low $\mathrm{pH}$
b. High magnetic anomaly
c. High phosphate
d. High conductivity
e. High total organic carbon (TOC)

Take additional samples in these areas of anomaly. At this point, the grid size and the sampling strategy can be changed, as well as using a 3-D sampling array. This will give the structure of the features through chemical detection.

4. The Trace Typing of organic residues or soils from features should be done with particular reference to the major essential biogenic elements with low mobility namely $\mathrm{P}$, 
$\mathrm{Mn}, \mathrm{K}, \mathrm{Fe}$. This is a necessary voluntary restriction to provide a pool of elements that demonstrated the most stability in a dynamic and evolving mutualism between the inorganic and organic, the non-living and living interface.

5. Elemental analysis of non-anthropogenic soil samples offsite will provide a background with which to compare the ASH and organic residue samples. If ash or residue element levels are greater than that of the soil background levels, then the following calculation can be made:

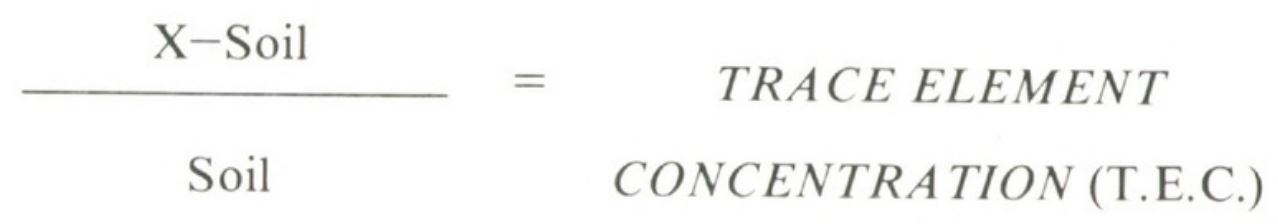

Where $\mathrm{X}=\mathrm{ASH}$, or organic residue concentration level.

6. We propose the idea of Trace Type. That is, then, a series of 5 T.E.C. measurements typifying a given feature. They are:

a. $\mathrm{PO}_{4}$

b. $\mathrm{Mn}$

c. $\mathrm{K}$

d. $\mathrm{Fe}$

e. Hyper-accumulating variable(s)

It is the Total Trace Type that must be utilized in standardization and comparison to residues within the site and to other reference materials.

7. Once the structure of the feature is established, one can potentially interpret or ascribe function(s) to the feature, relative to plant use. This is particularly feasible in cases where there was low plant diversity and use of hyperaccumulating plants. The soil background samples and those of the feature are analyzed by neutron activation analysis, using the 40 low mobility elements, if detectable. In turn, ancient and modern species are analyzed, utilizing available ethnobotanical evidence of species identified within the feature or site. A comparison of the results will allow one to specify the nature of plant utilization.

8. If there are primary trees that appear to have been in residence during site occupation, they should be cored and 
submitted for dendrochronological analysis and then further analyzed by neutron autoradiography. This may show details of occupational chronology by hyperaccumulation of trace elements in the tree through time. High levels suggest site occupation, low or diminishing levels unoccupied periods of time.

9. Additional calculations can be made from dendrochronological data (Tree Rings) and from the Trace Type of the contemporary canopy.

TOTAL T.E.C. DEND. DATA

TOTAL T.E.C. SOIL
Enrichment Ratio D

(Dendro)

TOTAL T.E.C. CANOPY

TOTAL T.E.C. SOIL

Enrichment Ratio C

(Canopy)

This Enrichment Ratio is indicative of the flow rate of the cycling process between elemental uptake and elemental return.

A comparison of modern enrichment processes Enrichment Ratio C compared to past ancient enrichment levels Enrichment Ratio D should bring greater understanding of the ecological conditions and of site occupations at particular locations.

We introduce these measurements of Trace Element Concentration (T.E.C.), of TRACE TYPING and of the Enrichment Ratios to stimulate the building of a data base that draws on both ancient and modern materials and that promises to give rise to not only ethnobotanical identifications but to a greater and deeper understanding of plant utilization and transport with respect to archaeological sites.

We look forward to examining the evidence for plant utilization on occupation sites, resulting in biogeochemical residues in the soil. If there are specific patterns of accumulation of elements in plant materials, then these patterns will be useful in interpretation. 


\section{ACK NOWLEDGMENTS}

This study and the development of this new analytical method has been a collaborative effort between the Ethnobotanical Laboratory of the Botanical Museum of Harvard University and the Center for Research and Development of the Peabody Museum of Archaeology and Ethnology. We wish to thank Professor Richard Evans Schultes, Director of the Botanical Museum, and Professor C. C. Lamberg-Karlovsky, Director of the Peabody Museum for their encouragement and support. We also thank K. Harris for assistance in compiling bibliographical data.

\section{BIBLIOGRAPHY}

Agricola

1467 DE RE METALLICA

Andrews-Jones, D. A.

1968 The Application of Geochemical Techniques to Mineral

Briver, F.L. Exploration, Mineral Ind. Bull. 11(6) 31p.

1976 New Clues to Stone Tool Function: Plant and Animal Residues,

Broderick, M. Amer. Antiquity 41(4) 478-484.

1977 Ascending Paper Chromatographic Technique in Archaeology, Lithic Use-Wear Analysis (ed., B. Hayden) N.Y., Academic Press, 375-384.

Brooks, R. R.

1972 Geobotany and Biogeochemistry in Mineral Exploration, Harper and Row, New York.

Cook, S. F. and R. F. Heizer

1965 Studies on the Chemical Analysis of Archaeological Sites,

University of California Publications in Anthropology, Berkeley, 2, $1-102$.

Pollock, G. E., C. -N Chang and S. E. Cronin

1977 Determination of the D and L isomers of some protein amino acids, Analytical Chemistry 49 (1) 2-7.

Rottlander and Schlichter

1979 Food identification of samples from archaeological sites, Archaeophysiko, 10, 260-267.

Shafer, H. J. and R. G. Holloway

1977 Organic Residue Analysis Determining Stone Tool Function, Lithic Use-Wear Analysis (ed., B. Hayden) N.Y., Academic Pres, 385-399.

Sjoberg, A.

1976 Phosphate Analysis of Anthropic Soils, J. Field Archaeology, 3 (4) 447-454. 
Weide, D. L.

1966 Soil $\mathrm{pH}$ as a guide to archaeological investigation, UCLA Archaeological Survey, Annual Report, Los Angeles, 155-163. 


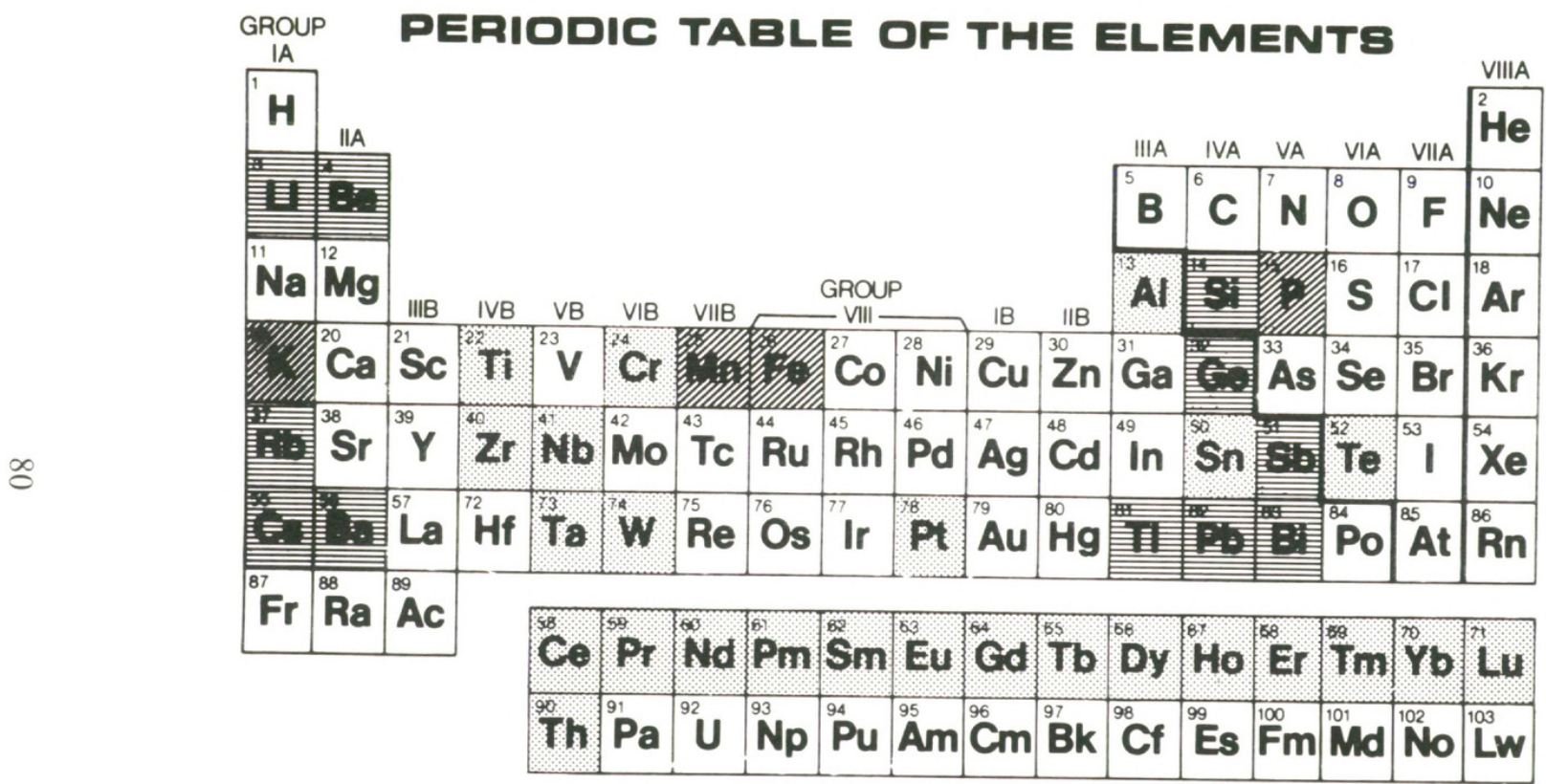

TABLE 1.

ELEMENTS WITH VERY LOW MOBILITY OR IMMOBILE: STIPPLED

ELEMENTS WITH LOW MOBILITY: BARRED

ELEMENTS WITH LOW MOBILITY WHICH ARE BIOGENIC: DIAGONALLY BARRED 


\section{$2 \mathrm{BHL}$ Biodiversity Heritage Library}

Coughlin, Elizabeth A and Ericson, Jonathan E . 1980. "Biogeochemical Residues as Ethnobotanical Indicators." Botanical Museum leaflets, Harvard University 28(1), 71-80. https://doi.org/10.5962/p.168642.

View This Item Online: https://www.biodiversitylibrary.org/item/31875

DOI: https://doi.org/10.5962/p.168642

Permalink: https://www.biodiversitylibrary.org/partpdf/168642

\section{Holding Institution}

Missouri Botanical Garden, Peter H. Raven Library

\section{Sponsored by}

Missouri Botanical Garden

\section{Copyright \& Reuse}

Copyright Status: Public domain. The BHL considers that this work is no longer under copyright protection.

This document was created from content at the Biodiversity Heritage Library, the world's largest open access digital library for biodiversity literature and archives. Visit BHL at https://www.biodiversitylibrary.org. 